\title{
Nasopharyngeal bacterial colonization in children - study hypothesis
}

\author{
Anca Streinu-Cercel ${ }^{1,2^{*}}$, Oana Streinu-Cercel ${ }^{1,2}$, Mihai Săndulescu ${ }^{1}$, Ioana Berciu ${ }^{1,2}$, Adrian Streinu-Cercel ${ }^{1,2}$ \\ From The 9th Edition of the Scientific Days of the National Institute for Infectious Diseases Prof Dr Matei Bals \\ Bucharest, Romania. 23-25 October 2013
}

\section{Background}

With monthly reports of decreased bacterial susceptibility to antibiotics and the soaring incidence of invasive infections, it becomes increasingly important to assess bacterial colonization, as this can easily constitute a reservoir for infection. Entering the community for kindergarten and school training is an important step for children, particularly since this may be associated with a change in the microbiota.

\section{Methods}

We aim to assess the nasal and pharyngeal flora in immune-competent children from the community, and institutionalized children with HIV infection or hematologic disorders. Bacterial colonization will be determined through the collection of nasopharyngeal swabs with subsequent culturing and species identification.

\section{Discussion}

It has become increasingly important to describe the flora of the human body in a wide array of physiologic and pathologic conditions. Given that resident bacteria can often represent a reservoir for infection, as is the case with infectious endocarditis following dental procedures, or sepsis following digestive bacterial translocation, we aim to better describe bacterial flora by assessing nasopharyngeal colonization in healthy and immune-compromised children and comparing antibiotic sensitivity profiles.

\section{Authors' details}

${ }^{1}$ Carol Davila University of Medicine and Pharmacy, Bucharest, Romania. ${ }^{2}$ National Institute for Infectious Diseases "Prof. Dr. Matei Balş", Bucharest, Romania.

\section{Published: 16 December 2013}

*Correspondence: anca_sc@yahoo.com

${ }^{1}$ Carol Davila University of Medicine and Pharmacy, Bucharest, Romania

Full list of author information is available at the end of the article
doi:10.1186/1471-2334-13-S1-P41

Cite this article as: Streinu-Cercel et al: Nasopharyngeal bacterial colonization in children - study hypothesis. BMC Infectious Diseases 2013 13(Suppl 1):P41.
Submit your next manuscript to BioMed Central and take full advantage of:

- Convenient online submission

- Thorough peer review

- No space constraints or color figure charges

- Immediate publication on acceptance

- Inclusion in PubMed, CAS, Scopus and Google Scholar

- Research which is freely available for redistribution

\section{() Biomed Central}

C Biomed Central

( 2013 Streinu-Cercel et al; licensee BioMed Central Ltd. This is an Open Access article distributed under the terms of the Creative Commons Attribution License (http://creativecommons.org/licenses/by/2.0), which permits unrestricted use, distribution, and reproduction in any medium, provided the original work is properly cited. 